\title{
New distributional records of non-native vascular plants in northern Italy
}

\author{
Filip Verloove $^{1^{*}}$, Nicola M. G. Ardenghi ${ }^{2}$
}

\begin{abstract}
New distributional records of non-native vascular plants are provided for the Italian regions Piemonte, Lombardia and EmiliaRomagna. Panicum barbipulvinatum is reported for the first time from Italy.
\end{abstract}

Key words: alien plants, distribution, Italy.

Riassunto - Nuove segnalazioni di piante vascolari alloctone per l'Italia settentrionale. Vengono forniti nuovi dati distributivi relativi ad alcune specie esotiche per le regioni Piemonte, Lombardia ed EmiliaRomagna. Panicum barbipulvinatum viene segnalato per la prima volta in Italia.

Parole chiave: distribuzione, Italia, piante alloctone.

\section{INTRODUCTION}

Invasive Alien Species (IAS) threaten biodiversity, society, human-health, well-being and economy. The annual economic impact to Europe is estimated $€ 12.5$ to 20 billion. Prompt detection of new invasive species as well as their correct taxonomic identification is widely considered to be of the utmost importance (Genovesi et al., 2010). Although the non-native, potentially invasive flora of Italy received a lot of attention in recent years (e.g. Celesti-Grapow et al., 2009a, b; Celesti-Grapow et al., 2010), and the knowledge evolved accordingly, the work is never accomplished and updates are constantly required (see e.g. Ardenghi et al., 2014). In our globalized world the influx of new alien species seems to be infinite. Also, the taxonomic knowledge of researchers and field workers constantly improves which enable them to better

\footnotetext{
${ }^{1}$ Botanic Garden of Meise, Nieuwelaan 38, B-1860 Meise, Belgium

${ }^{2}$ Department of Earth and Environmental Sciences, University of Pavia, Via S. Epifanio 14, I-27100 Pavia, Italy

E.mail: sahfen@hotmail.com

* Corresponding author: filip.verloove@br.fgov.be

(C) 2015 Filip Verloove, Nicola M. G. Ardenghi
}

Received: $10^{\text {th }}$ January 2015

Accepted for publication: $19^{\text {th }}$ April 2015 assess the exact identity of newly detected and already present invaders.

With that purpose the first author visited in September 2014 riparian habitats in the plain of river Po and its many tributaries, primarily in order to improve the knowledge on Cyperus in northern Italy (Verloove, 2014; Verloove \& Saiani, 2015). This scientific mission fits in COST Action TD1209 'European Information System for Alien Species' (http://www.cost.eu/COST Actions/fa/Actions/ TD1209, retrieved on December 2014) and facilitates enhanced knowledge gathering and sharing through a network of experts, providing support to a European IAS information system. This, in turn, enables effective and informed decision-making in relation to IAS. On that occasion he was hosted by the University of Pavia where, in collaboration with the second author, field work was performed, among others, in the region Lombardia.

In the present paper new distributional records for the Italian regions Piemonte, Lombardia and Emilia-Romagna are presented for sixteen non-native species of vascular plants (others than Cyperus). One species, Panicum barbipulvinatum Nash, is reported for the first time from Italy.

\section{MATERIALS AND METHODS}

The taxa are arranged in alphabetical order. Each entry includes the currently accepted name of the taxon and the family to which it belongs (according to APG III, 2009), its status and distribution in Italy (following Celesti-Grapow et al., 2009a, 2009b), data from the herbarium label (for acronyms see Thiers, 2014 onwards) and additional notes about its native and secondary distribution area, invasive behavior, ecology and, if relevant, identification aids and taxonomical and nomenclatural comments.

Original photographs are provided for some of the taxa.

\section{RESULTS}

Amaranthus palmeri S.Watson, Proc. Amer. Acad. Arts, 12: 274.1877.

(Amaranthaceae)

Naturalized neophyte new to the flora of Piemonte (Conti et al., 2005; Celesti-Grapow et al., 2009a; Iamonico et al., 2015; Iamonico, 2015). 
ITALY. Piemonte. Prov. Alessandria: Tortona, river Scrivia at railway bridge, gravelly riverbed, locally, along with A. tuberculatus, 09.09.2014, F. Verloove 11206 (BR).

A native of the southwestern U.S.A. and Mexico, Amaranthus palmeri now occurs as a weed in Europe, Asia and Australia (Mosyakin \& Robertson, 2003). In Italy it was recently discovered in Emilia-Romagna, in the province of Ravenna (Iamonico et al. 2015; Iamonico, 2015). While for many decades it remained strictly casual in Europe (often associated with imported cereals or soybeans; e.g. Verloove \& Vandenberghe, 1993), it managed to naturalize locally in recent times, especially in the Mediterranean area. In Spain naturalized populations were detected around Lleida in 2007 (Verloove \& Sánchez Gullón, 2008) and soon afterwards it proved to have become a troublesome agricultural weed in maize fields there (Recasens et al., 2013). Elsewhere in the Mediterranean area stable populations are known from Israel and Greece (Raus \& Raabe, 2006). In Ravenna province the plant was regarded as casual (Iamonico et al., 2015; Iamonico, 2015), even though the species was confirmed for at least two years consecutively in the same site (see http://www.actaplantarum.org/floraitaliae/viewtopic.php? $\mathrm{f}=106 \& \mathrm{t}=67866$, retrieved on December 2014); in Tortona the population is clearly naturalized.

Amaranthus palmeri is a dioecious species. In Italy a related species, $A$. tuberculatus (Moq.) J.D.Sauer, has been known since 1975 (Soldano, 1982). It now has become an invasive species in riparian habitats and cultivated fields (Banfi \& Galasso, 2010), especially in the plain of river Po and its tributaries. Since A. palmeri is equally aggressive and occurs in the same type of habitats, similar behavior is predictable. Both species are rather alike and may have been confused. A. palmeri has much longer bracts and tepals, the inflorescence therefore being stiff and prickly in appearance. In Tortona, along Scrivia river, both grow sympatrically.

Bidens connatus Muhl. ex Willd., Sp. Pl., ed. 4 [Willdenow], 3 (3): 1718 (-1719). 1803. [Fig. 1]

(Asteraceae)

Naturalized neophyte new to the flora of Piemonte (Conti et al., 2005; Celesti-Grapow et al., 2009a; Banfi \& Galasso, 2010).

ITALY. Piemonte. Prov. Alessandria: Villanova Monferrato, W of motorway E25, rice fields, 12.09.2014, F. Verloove 11101 (BR).

Bidens connatus is originally native in North America but known as a more or less widely naturalized xenophyte in Europe (e.g. Schumacher, 1941; Debray, 1963). In Italy it was known so far from Lombardia, Emilia-Romagna, Friuli-Venezia Giulia, Marche and Veneto, either as a casual, naturalized or invasive alien (Celesti-Grapow et al., 2009a; Ardenghi, 2015).

In fact, its genuine distribution and degree of naturalization should be critically reassessed, the species being much reminiscent of native $B$. tripartitus L. It is best distinguished from the latter by leaves usually undivided and cypselae 4-angled (not flattened) with usually tuberculate faces (Strother \& Weedon, 2006).

In September 2014 Bidens connatus was recorded on several occasions. In addition to the locality cited above, it was also seen in Valenza, Bastida Pancarana, Boretto, Ficarolo, Mezzano, Piacenza, Ravalle, San Rocco al Porto and Viadana (all along river Po) and in Serravalle Scrivia (along river Scrivia). It is obviously much more widespread, firmly established but widely overlooked.

It should be recalled that according to Art. 62.2(a) of the International Code of Nomenclature (McNeill et al., 2012), Bidens should be treated as a compound, "Bi-dens", the last word (dens, dentis) being male; then the specific epithet should be "connatus" instead of "connata" (see also next species). Even though initially recommended by the Report of the Committee for Spermatophyta (Brummitt, 2000), the proposal to conserve the name Bidens with a conserved gender (Harriman, 1998), was finally not upheld (McNeill et al., 2006, App. III) (Banfi \& Galasso, 2010).

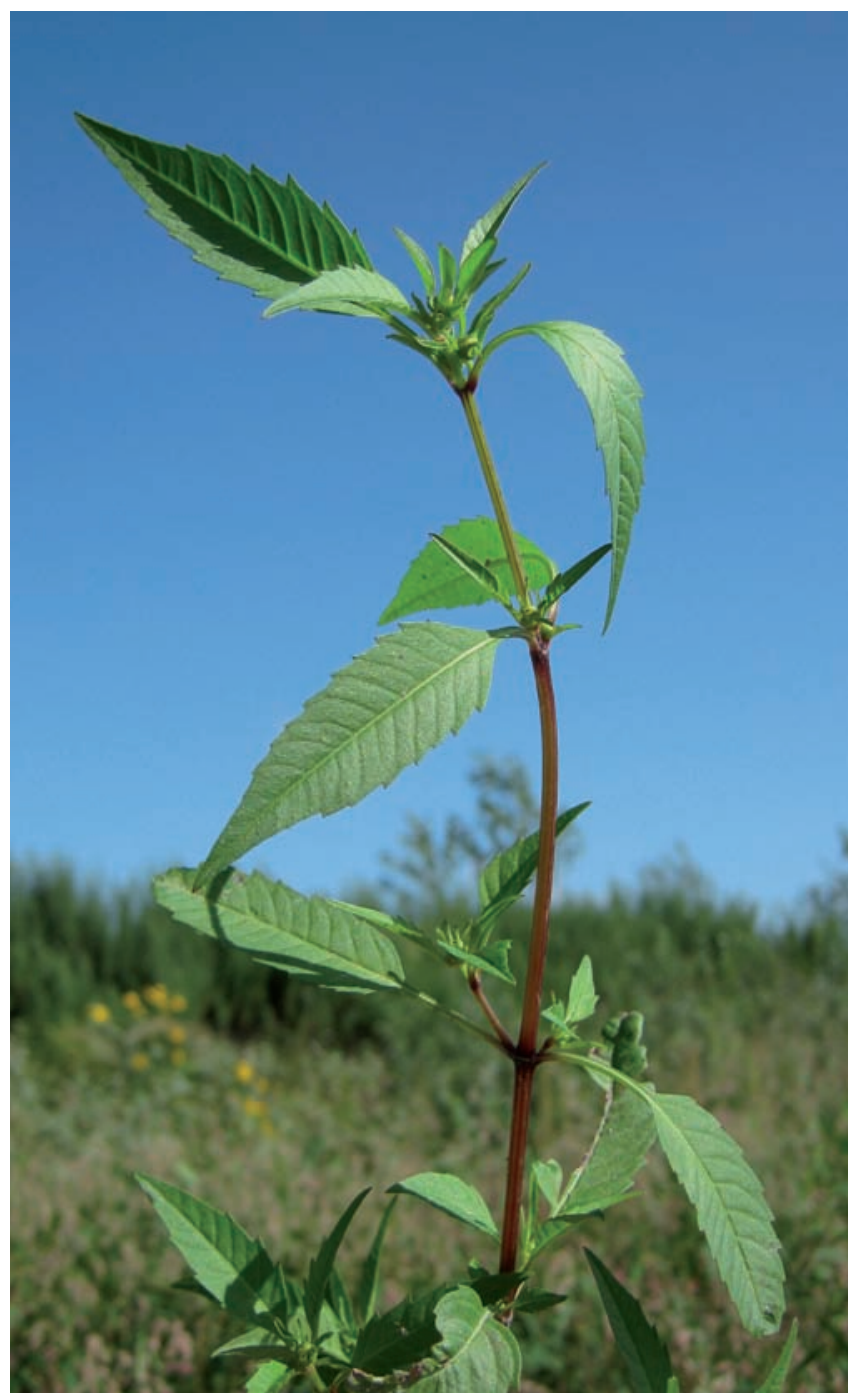

Fig. 1 - Bidens connatus, Bastida Pancarana (PV), September 2014 (Photo: N. Ardenghi). 
Bidens vulgatus Greene, Pittonia, 4 (21): 72. 1899. [Fig. 2]

(Asteraceae)

Naturalized neophyte new to the flora of Lombardia and Emilia-Romagna (Conti et al., 2005; Celesti-Grapow et al., 2009a; Banfi \& Galasso, 2010).

ITALY. Lombardia. Prov. Cremona: Casalmaggiore, river Po, damp track in woodland, locally frequent, 14.09.2014, F. Verloove 11090 (BR, MSNM); Prov. Pavia: Gambolò, Cascina Portalupa (UTM ED50: 32T 495784.5013034), margine di sentiero in querco-carpineto, con Erigeron canadensis, Prunella vulgaris, Glechoma hederacea, $73 \mathrm{~m}$, 17.10.2014, N. Ardenghi, P. Cauzzi \& S. Pedrini (MSNM); Prov. Pavia: Stradella, San Zeno, sponda destra del torrente Versa all'incirca all'altezza della rotonda tra viale Resistenza e la SP201 (UTM ED50: 32T 524108.4989963), vigneto, $86 \mathrm{~m}, 18.10 .2014$, N. Ardenghi (MSNM); Prov. Milano: Milano, stazione FFSS di Milano-Rogoredo (UTM ED50: 32T 518642.5031188), aiuola, $109 \mathrm{~m}, 28.11 .2014, N$. Ardenghi (MSNM).

This is a widespread species in North America (Strother \& Weedon, 2006). Like the preceding, it is poorly known and overlooked in Europe, although known since many decades (e.g. Schumacher, 1941; Debray, 1963). Up to present it was known in Italy only from Friuli-Venezia Giulia (Celesti-Grapow et al., 2009a). Bidens vulgatus is much reminiscent of $B$. frondosus L. but often more ro- bust with larger flower heads and with a higher number of calyculi (10-16 vs. usually 8).

In addition to the localities cited above, it was also detected along river Po in Boretto (Emilia-Romagna). It may have been widely overlooked elsewhere.

Cardamine hamiltonii G.Don, Gen. Hist., 1: 167. 1831.

三Cardamine debilis D.Don, Prodr. Fl. Nepal.: 201. 1825, nom. illeg.

$\equiv$ Cardamine flexuosa With. subsp. debilis O.E.Schulz, Bot. Jahrb. Syst., 32 (4): 478. 1903.

(Brassicaceae)

Naturalized neophyte new to the flora of Piemonte (Conti et al., 2005; Celesti-Grapow et al., 2009a; Ardenghi \& Mossini, 2014).

ITALY. Piemonte. Prov. Vercelli: Arborio, river Sesia $\mathrm{N}$ of the bridge, exposed river bank, 06.09.2014, F. Verloove 11043 (BR).

Cardamine hamiltonii is a poorly known but widely spread species in many parts of Europe. It has long been confused with $C$. flexuosa but molecular data have demonstrated that it is a distinct entity, apparently native in East Asia (e.g. Lihová et al., 2006; Bleeker et al., 2008). It is distinguished from the latter by the absence at flowering of a distinct basal rosette and the markedly trilobed leaflets that usually have a glabrous upper leaf surface (cfr. Mansanet-Salvador et al., 2015).

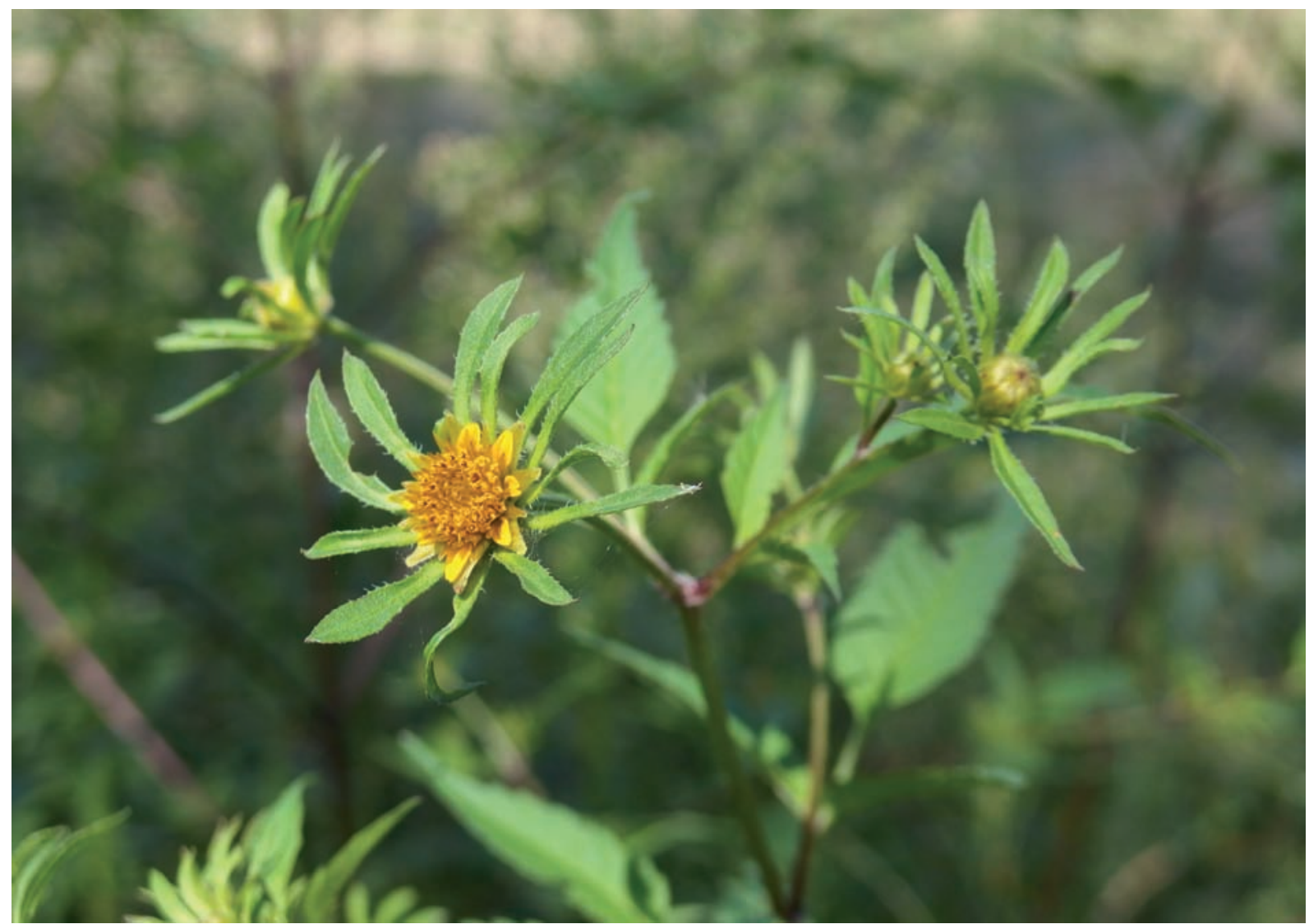

Fig. 2 - Bidens vulgatus, Martignana di Po (CR), September 2014 (Photo: F. Verloove). 
Al-Shehbaz et al. (2010) referred to this taxon as Cardamine flexuosa subsp. debilis but agreed that it should be recognized at species level and its correct name be sought. In recent times it became clear that the name $C$. hamiltonii probably can be applied for these plants (e.g. Bomble, 2014; Ardenghi et al., 2015; Dirkse et al., 2015).

For Italy this species was recently reported for the first time from Lombardia and Toscana (Ardenghi \& Mossini, 2014). In September 2014 it was seen in Arborio alongside river Sesia (see above), in an area from where it had been claimed before (Dienst, 2007). It was also seen as an urban weed in Vercelli and in rice fields in Albano Vercellese and Robbio. It is well-established, weedy and doubtlessly widely overlooked elsewhere in Italy.

Cucurbita maxima Duchesne, Essai Hist. Nat. Courges: 7. 1786.

(Cucurbitaceae)

Confirmation of casual neophyte for the flora of Piemonte (Conti et al., 2005; Celesti-Grapow et al., 2009a).

ITALY. Piemonte. Prov. Vercelli: Vercelli, city center close to river Sesia, roadside, 07.09.2014, F. Verloove 11069 (BR).

Doubtlessly an ephemeral alien, this species unlike in other parts of Europe, is frequently cultivated in northern Italy, its fruits being used in different traditional dishes. It is distinguished from the latter by its peduncle that is terete and becoming corky in fruit. Its leaves are almost entire or very shallowly lobed and softly hairy above. $C$. pepo, in contrast, has peduncles that are deeply furrowed in fruit (conspicuously angled, not corky) and its leaves are deeply 5-lobed and hirsute hairy above.

Cucurbita maxima was considered doubtful for Piemonte by Conti et al. (2005) and not listed from that region by Celesti-Grapow et al. (2009a).

Digitaria violascens Link, Hort. Berol. [Link], 1: 229. 1827.

(Poaceae)

Naturalized neophyte new to the flora of the province of Alessandria (Piemonte) (Verloove et al., 2011).

ITALY. Piemonte. Prov. Alessandria: Valenza, river Po S of the bridge, sandy river bank, 07.09.2014, F. Verloove 11088 (BR).

A native from the Old World tropics Digitaria violascens has long been overlooked in southern Europe. Verloove (2008) cited records from France and Italy (prov. Novara in Piemonte), subsequently also from Spain (Verloove \& Sánchez Gullón, 2008). Later, it turned out to be much more widespread in northwestern Italy (Verloove et al., 2011). In Piemonte it was previously recorded in the provinces Biella, Torino, Verbano-Cusio-Ossola and Vercelli (Verloove et al., 2011) and in September 2014 it was also seen along river Po near Valenza, apparently for the first time in the province of Alessandria.

Muhlenbergia frondosa (Poir.) Fernald, Rhodora, 45 (534): 235. 1943.

(Poaceae)

Naturalized neophyte new to the flora of Emilia-Romagna (Conti et al., 2005; Celesti-Grapow et al., 2009a).
ITALY. Emilia-Romagna. Prov. Reggio nell'Emilia: Boretto, river Po E of the bridge, riparian woodland, locally, 13.09.2014, F. Verloove 11000 (BR, MSNM).

Muhlenbergia frondosa is a native species in southern Canada and the contiguous U.S.A. (Peterson, 2003). It is only rarely seen outside of its native distribution range. However, in Italy it is known since several decades from Piemonte (Soldano, 1977) where it is naturalized, for instance in riparian woodland alongside river Sesia. In recent years it seems to spread in northern Italy: Bertolli \& Prosser (2013) reported about its discovery in Trentino-Alto Adige and in September 2014 it was also detected alongside river Po in Boretto. This species is rather inconspicuous and often very reluctant to flower; it may be more widespread but overlooked.

Oenothera pedemontana Soldano, Rivista Piemont. Storia Nat., 4: 131. 1983. [Fig. 3]

(Onagraceae)

Naturalized neophyte new to the flora of Lombardia (Soldano, 1983; Soldano, 1993; Banfi \& Galasso, 2010).

ITALY. Lombardia. Prov. Pavia: Bereguardo, river Ticino close to the bridge, sandy river bank, 11.09.2014, F. Verloove 11016 (BR).

This microspecies from the Oenothera biennis aggregate (possibly a hybrid of the latter; Dietrich et al., 1997) was originally described from Piemonte, the type being from Saluggia in Torino province (Soldano, 1983). It is now more or less widely dispersed in Piemonte (see map in Cecere et al., 2012) but had never been recorded outside of this region (Conti et al., 2005; Celesti-Grapow et al., 2009a). In September 2014 this species was found growing in abundance on the sandy banks of river Ticino in Bereguardo.

Characteristic features of Oenothera pedemontana are its tall habit (stem up to $230 \mathrm{~cm}$ long), late flowering, presence of glandular hairs on the hypanthium, petals wider than long (ca. $26 \times 17-23 \mathrm{~mm}$ ) and relatively small capsules ca. 18-33 mm long with emarginate capsule teeth (e.g. Soldano, 1993).

Panicum barbipulvinatum Nash, Mem. New York Bot. Gard., 1: 21. 1900.

= P. riparium H.Scholz, Feddes Repert., 113 (3-4): 275. 2002.

(Poaceae)

Naturalized neophyte new to the flora of Italy (Piemonte) (Conti et al., 2005; Celesti-Grapow et al., 2009a).

ITALY. Piemonte. Prov. Alessandria: Valenza, river Po $\mathrm{S}$ of the bridge, sandy river bank, very common, 07.09.2014, F. Verloove 11060 (BR); Prov. Alessandria: Arquata Scrivia, river Scrivia $\mathrm{N}$ of the bridge, gravelly river bed, frequent, 09.09.2014, F. Verloove 11062 (BR).

Panicum barbipulvinatum is an enigmatic species originating in temperate North America. Its taxonomic status is debated: in its area of origin it is merely included in the variability of $P$. capillare L. by modern authors (e.g. Freckmann \& Lelong, 2003). In Europe, however, where 
only part of the genetic diversity of the latter is present, it is easily distinguished. This inspired Scholz (2002) to describe it as a neo-endemic species new to science, $P$. riparium. Recently, Amarell (2013) demonstrated that Scholz' new species in fact perfectly corresponds with the American P. barbipulvinatum. Moreover, he advocated, like Scholz, that this taxon should be accepted at species rank (as is, for instance, $P$. hillmanii Chase from the same species complex). His point of view was followed in the recently published Flora Gallica (Tison \& de Foucault, 2014).

Panicum barbipulvinatum has a laxer inflorescence with spikelets on short pedicels that are tightly appressed. The narrower spikelets are long-acuminate at apex. This particular combination of features renders the plant a characteristic jizz that is fairly different from that of $P$. capillare.

In September 2014 Panicum barbipulvinatum was seen on several occasions in Piemonte, always on exposed sandy or gravelly banks of rivers Po and Scrivia.

Panicum philadelphicum Bernh. ex Trin., Gram. Panic. [Trinius]: 216. 1826.

= Panicum gattingeri Nash, Fl. S.E. U.S. [Small], 92 (1327). 1903.

(Poaceae)

Confirmation of naturalized neophyte for the flora of the province of Alessandria (Piemonte) (Soldano \& Verloove, 2007).

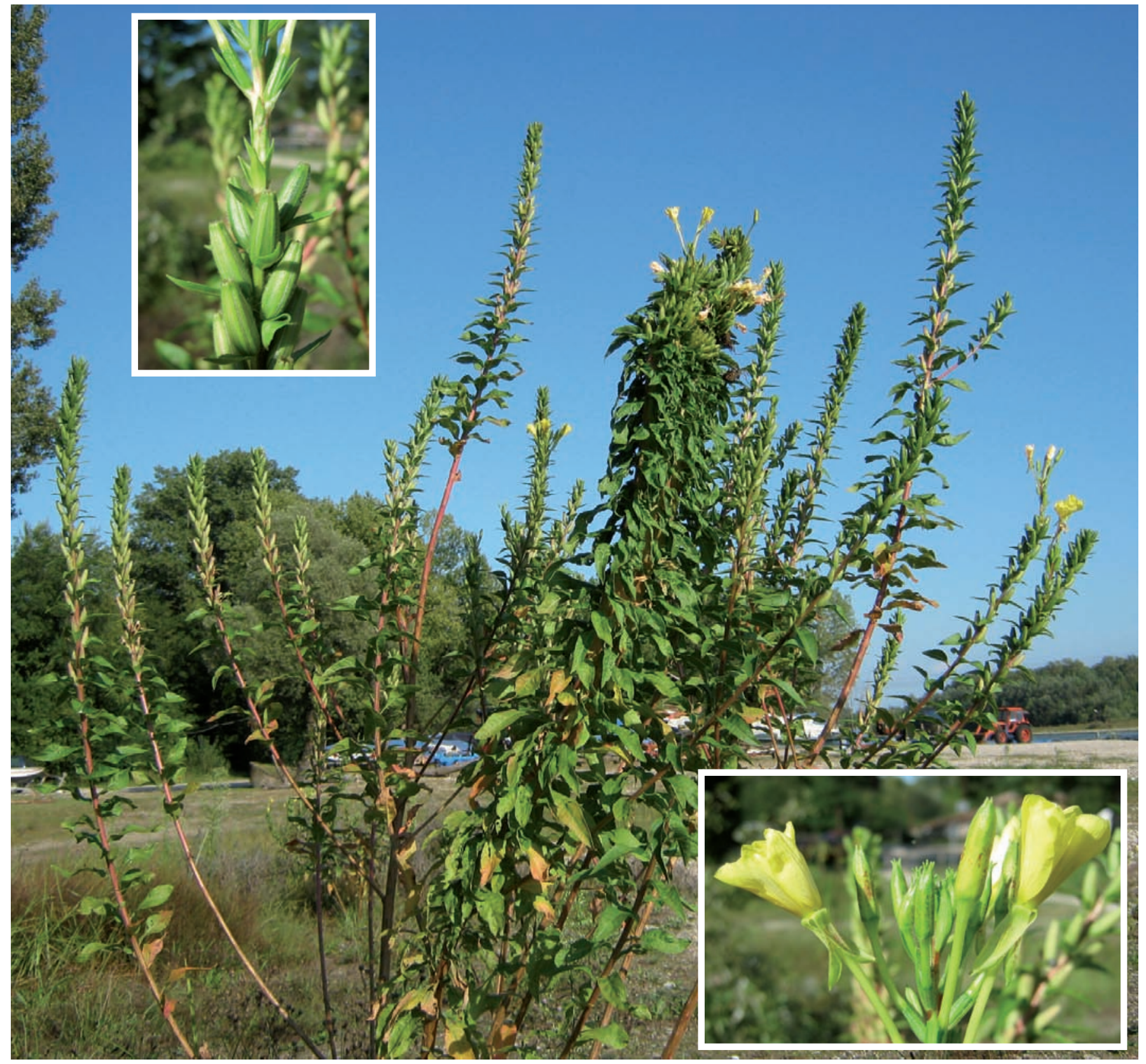

Fig. 3 - Oenothera pedemontana, Bereguardo (PV), September 2014 (Photo: N. Ardenghi). 
ITALY. Piemonte. Prov. Alessandria: Valenza, river Po $\mathrm{S}$ of the bridge, sandy river bank, few individuals, 07.09.2014, F. Verloove 10990 (BR).

This North American species was only known from a single, historical record in Alessandria province (Soldano \& Verloove, 2007). Its present-day presence is here confirmed. In Piemonte, it is also known from Torino province (Verloove \& Selvaggi, 2011), also along river Po.

Panicum philadelphicum is much reminiscent of $P$. capillare and both possibly have been confused in parts of Europe. It is readily distinguished by its panicles that are only ca. $1 / 3$ the total height of the plant, the base of the peduncle that is not breaking at maturity and the slightly smaller spikelets that are acute at apex, not acuminate.

Perilla frutescens (L.) Britton, Mem. Torrey Bot. Club, 5 (18): 277. 1894. [Fig. 4]

(Lamiaceae)

Casual neophyte new for the flora of Piemonte (Conti et al., 2005; Celesti Grapow et al., 2009a).

ITALY. Piemonte. Prov. Alessandria: Basaluzzo, tor- rente Lemme close to SP 160, gravelly riverbed, 4 individuals, 08.09.2014, F. Verloove 11085 (BR).

Perilla frutescens from Asia is widely cultivated as an ornamental or as an oilseed crop. Up to present it has been recorded in Italy in Lombardia and Veneto, always as a casual alien (Celesti-Grapow et al., 2009a). It is here reported for the first time from Piemonte. In addition to the locality cited above, it was also seen in Arquata Scrivia along river Scrivia. It does not seem to naturalize (yet).

Persicaria pensylvanica (L.) M.Gómez, Anales Inst. Segunda Enseñ., 2: 278. 1896.

(Polygonaceae)

Naturalized neophyte new for the flora of the province of Mantova (Lombardia) (Banfi \& Galasso, 2010).

ITALY. Lombardia. Prov. Mantova: Viadana, river Po $\mathrm{W}$ of the bridge, sandy river bank, few plants, 15.09.2014, F. Verloove 11058 (BR).

A native of North America, this species became naturalized in Europe, especially in riparian habitats. In Italy it is known from the northernmost regions (Celesti-Grapow et al., 2009a). It is here reported for the first time from Mantova province in Lombardia.

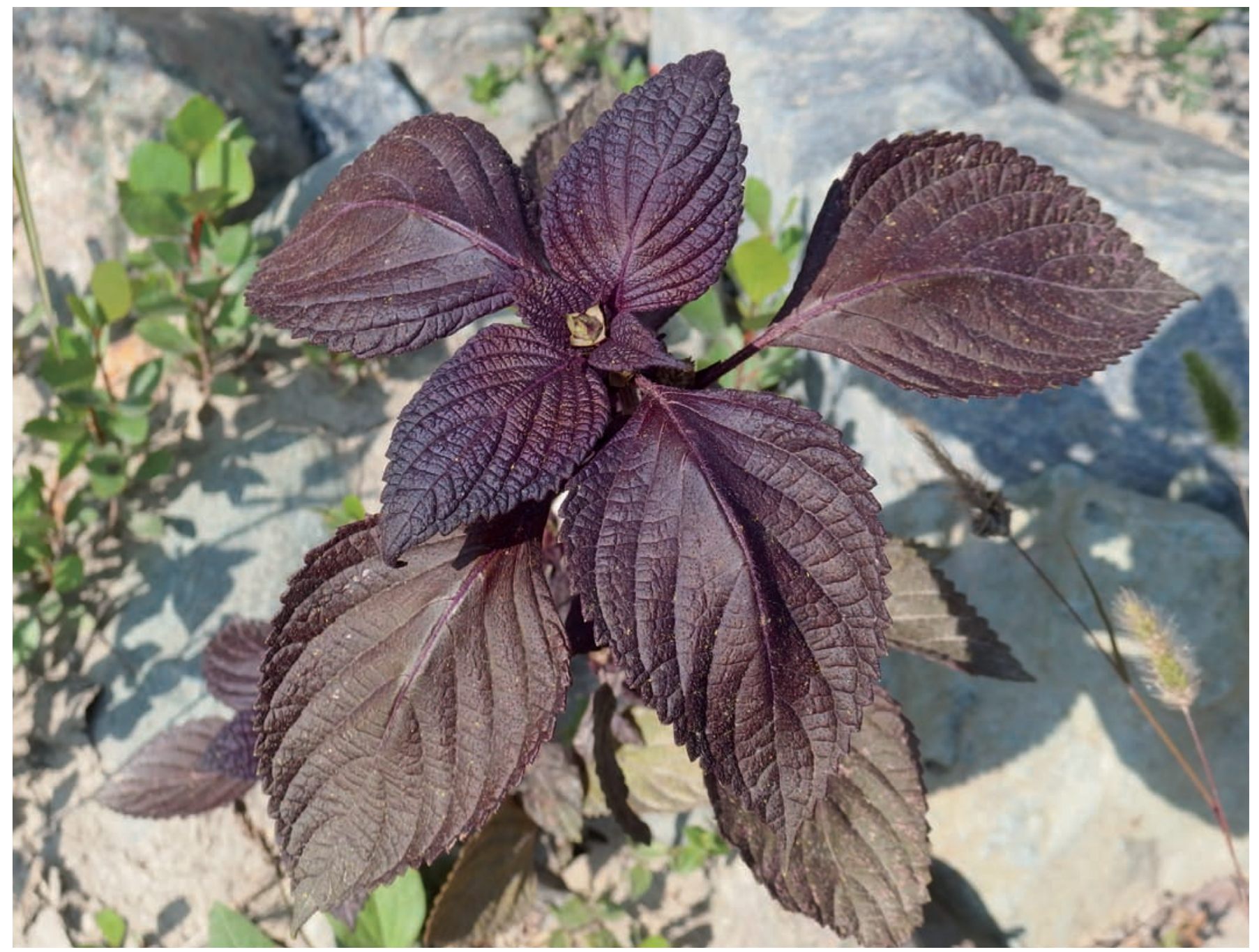

Fig. 4 - Perilla frutescens, Basaluzzo (AL), September 2014 (Photo: F. Verloove). 
This species is obviously naturalized along river Po but usually occurs in small populations. It does not seem to be an aggressive invader.

Populus deltoides W.Bartram ex Marshall, Arbust. Amer.: 106. 1785. [Fig 5]

(Salicaceae)

Casual neophyte new to the flora of the province of Lodi (Lombardia) (Banfi \& Galasso, 2010).

ITALY. Lombardia. Prov. Lodi: San Rocco al Porto, river Po $\mathrm{W}$ of the bridge, river bank, several young, selfsown trees, 13.09.2014, F. Verloove 11059 (BR).

This North American native is widely planted in Europe, although much less so than $P$. $\times$ canadensis Moench (pro sp.), its hybrid with native $P$. nigra L. It is reported to be an exceptional escape from cultivation in Lombardia, only being known from three localities in the Pavia area since 1905 (Banfi \& Galasso, 2010; Ardenghi, 2013). In San Rocco al Porto several young, obviously self-sown trees were seen on the sandy banks of river Po.

Populus deltoides is a distinct species with leaves up to $18 \mathrm{~cm}$ long or even longer, provided with more prominent and hooked marginal teeth. These features distinguish it from juvenile individuals of $P$. $\times$ canadensis, which usu- ally bear leaves larger than those of the adult trees (see Eckenwalder, 2010).

Rotala ramosior (L.) Koehne, Fl. Bras. (Martius), 13 (2): 194. 1877.

(Lythraceae)

Naturalized neophyte new to the flora of the province of Alessandria (Piemonte) (Celesti Grapow et al., 2009a).

ITALY. Piemonte. Prov. Alessandria: Villanova Monferrato, rice fields, 12.09.2014, F. Verloove 11079 (BR).

Rotala ramosior originally is an American species but it occurs in the Old World as a weed of rice fields, for instance in Italy and the Philippines (Cook, 1979). In Italy it was first discovered in Piemonte in 1972 (Cook, 1973), subsequently also in Lombardia (Banfi \& Galasso, 2010). In the past decades it has repeatedly been confirmed from Piemonte (e.g. Soldano, 1977; Abbà, 1980; Varalda et al., 1984; Desfayes, 2005) but it seemed to be confined to the province of Vercelli, from where it was originally reported by Cook (1973). In September 2014 it was found, apparently for the first time, in the province of Alessandria. It was found growing in quantity, with Ammannia coccinea Rottb. and other weeds, in a rice field near Villanova Monferrato.

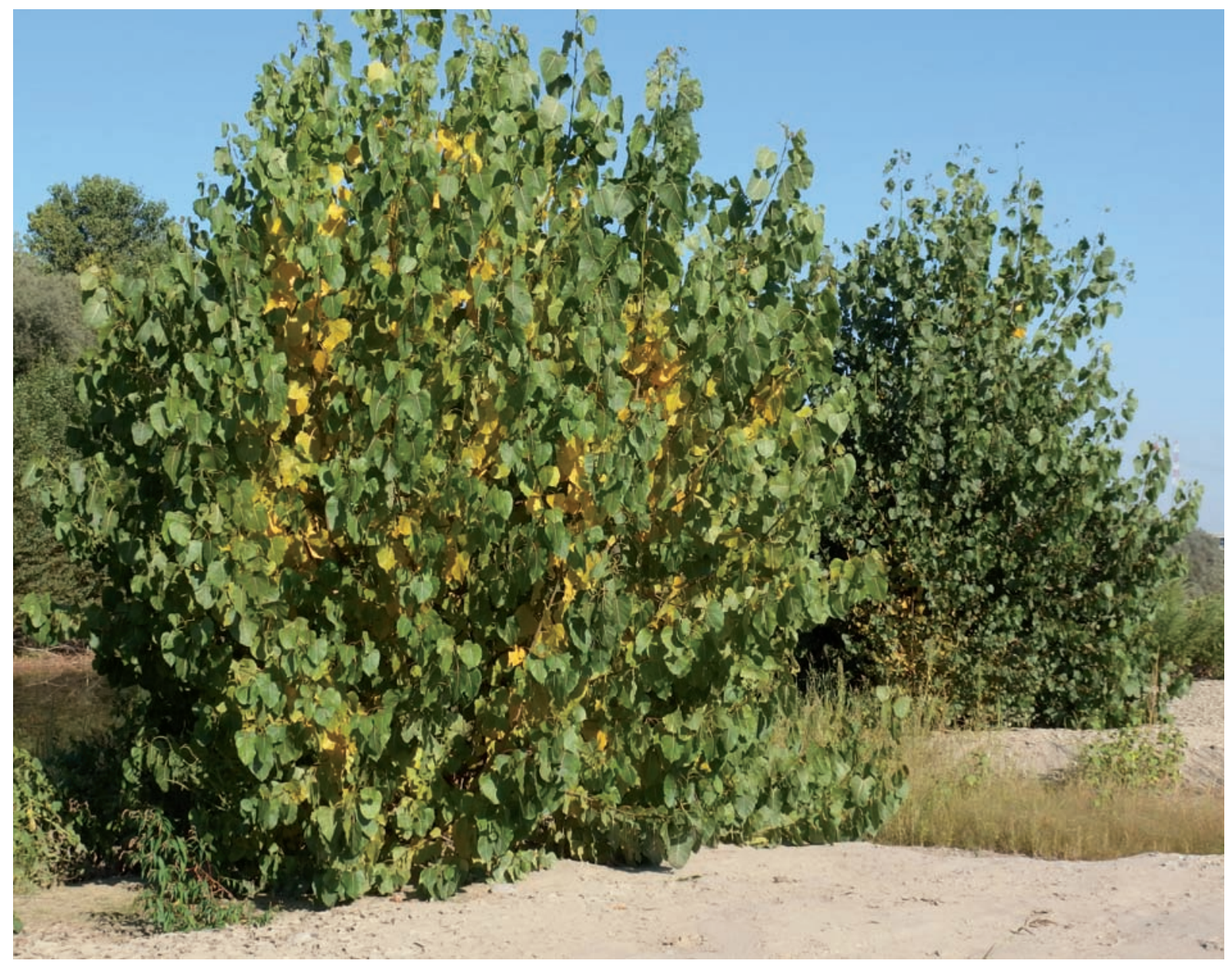

Fig. 5 - Populus deltoides, San Rocco al Porto (LO), September 2014 (Photo: F. Verloove). 
Symphyotrichum pilosum (Willd.) G.L.Nesom var. pringlei (A.Gray) G.L.Nesom, Phytologia, 77 (1994, 3): 289. 1995.

(Asteraceae)

Naturalized neophyte new to the flora of Piemonte (Conti et al., 2005; Celesti-Grapow et al., 2009a).

ITALY. Piemonte. Prov. Vercelli: Ghislarengo, ca. $1.5 \mathrm{~km} \mathrm{SW}$ of the village, abandoned gravel pit, common, 06.09.2014, F. Verloove 10985 (BR, MSNM).

Symphyotrichum pilosum is native in eastern North America (Brouillet et al., 2006) but widely cultivated as an ornamental in Europe. It is a poorly known species that has been confused with $S$. ericoides (L.) G.L.Nesom, $S$. lateriflorum (L.) Á.Löve \& D.Löve and even S. lanceolatum (Willd.) G.L.Nesom. Italian claims of the first two species are mostly erroneous and referable to $S$. pilosum (Banfi \& Galasso, 2010). The latter is fairly characteristic in having pedicels with numerous linear to subulate bracts and phyllaries with acute, spinulose apices. Stems and leaves may be either pilose to hirsute (var. pilosum) or glabrous (var. pringlei).

In Italy Symphyotrichum pilosum was only known with certainty from Lombardia (Banfi \& Galasso, 2010) although it may have been overlooked elsewhere. In Ghislarengo it has invaded rough ground in an abandoned quarry. It looks perfectly established there.

Symphyotrichum squamatum (Spreng.) G.L.Nesom, Phytologia, 77 (1994, 3): 292. 1995.

(Asteraceae)

Naturalized neophyte new to the flora of the province of Alessandria (Piemonte) (Pistarino et al., 1999).

ITALY. Piemonte. Prov. Alessandria: Tortona, bridge over river Scrivia, at entrance of A7 motorway, rough, bare ground, 09.09.2014, F. Verloove 11037 (BR).

This South American species is fast spreading and considered invasive in large parts of the Mediterranean area, including Italy (Celesti-Grapow et al., 2009a). In the Piemonte region it was known from Torino and Cuneo provinces (Pistarino et al., 1999) but not yet from Alessandria.

\section{Acknowledgements}

Daniela Bouvet and Alberto Selvaggi (Torino) and Gabriele Galasso (Milano) are acknowledged for checking data from the Piemonte and Lombardia regions respectively. John Strother (U.S.A.) and Jean-Marc Tison (France) helped with the identification of Bidens vulgatus, as did Adriano Soldano (Vercelli) for Oenothera pedemontana. Maurizio Tabacchi (Vercelli) is thanked for his assistance in rice fields in Piemonte. Finally, field work by the first author in September 2014 was granted by COST (Cooperation in Science and Technology), Action TD1209.

\section{REFERENCES}

Abbà G., 1980 - Flora esotica del Piemonte. Specie coltivate spontaneizzate e specie avventizie. Atti della Società Toscana di Scienze Naturali residente in Pisa. Memorie, serie B, 86: 263-302.
Al-Shehbaz I. A., Marhold K. \& Lihová J., 2010 - Cardamine. In: Flora of North America North of Mexico. Flora of North America Editorial Committee (ed.). Oxford University Press, New York, Oxford, 7: 464484.

Amarell U., 2013 - Panicum riparium - eine neoindigene Art Europas? Kochia, 7: 1-24.

APG III, 2009 - An update of the Angiosperm Phylogeny Group classification for the orders and families of flowering plants. APG III. Botanical Journal of the Linnaean Society, 161 (2): 105-121.

Ardenghi N. M. G., 2013 - Notulae 143-161. In: Notulae ad plantas advenas longobardiae spectantes: 3 (141208). Galasso G. \& Banfi E. (eds.). Pagine Botaniche, 36 (2012): 19-27.

Ardenghi N. M. G., 2015 - Notulae 269-272. In: Notulae ad plantas advenas Longobardiae spectantes: 5 (263310). Galasso G. \& Banfi E. (eds.). Pagine Botaniche, 38 (2014): 22-23.

Ardenghi N. M. G., Banfi E. \& Galasso G., 2014 - Notulae ad plantas advenas Longobardiae spectantes: 5 anni di aliene in Lombardia (2010-2014). In: Floristica, Sistematica ed Evoluzione. Comunicazioni. Orto Botanico di Roma, La Sapienza Università di Roma, 21-22 novembre 2014. Peruzzi L. \& Domina G. (eds.). Società Botanica Italiana, Gruppo per la Floristica, Sistematica ed Evoluzione, Firenze: 4950.

Ardenghi N. M. G., Cauzzi P. \& Galasso G., 2015 - Cardamine hamiltonii. In: Euro+Med-Checklist Notulae, 4. Raab-Straube E. von \& Raus T. (eds.). Willdenowia, 45 (1): 121-122.

Ardenghi N. M. G. \& Mossini S., 2014 - Cardamine flexuosa subsp. debilis. In: Euro+Med-Checklist Notulae, 3. Raab-Straube E. von \& Raus T. (eds.). Willdenowia, 44 (2): 292.

Banfi E. \& Galasso G. (eds.), 2010 - La flora esotica lombarda. Museo di Storia Naturale di Milano, Milano: 1-274 + Cd-Rom.

Bertolli A. \& Prosser F., 2013 - Segnalazioni Floristiche Tridentine. IX. Annali dei Musei Civici-Rovereto. Sezione: Archeologia, Storia, Scienze Naturali, 29: 131-174.

Bleeker W., Klausmeyer S., Peintinger M. \& Dienst M., 2008 - DNA sequences identify invasive alien Cardamine at Lake Constance. Biological Conservation, 141 (3): 692-698.

Bomble F. W., 2014 - Japanisches Reisfeld-Schaumkraut (Cardamine hamiltonii) in Aachen / Japanese rice field Bitter-cress (Cardamine hamiltonii) in Aachen (North Rhine-Westphalia, Germany). Veröffentlichungen des Bochumer Botanischen Vereins, 6: 1-5.

Brouillet L., Semple J. C., Allen G. A., Chambers K. L. \& Sundberg S. D., 2006 - Symphyotrichum. In: Flora of North America North of Mexico. Flora of North America Editorial Committee (ed.). Oxford University Press, New York, Oxford, 20: 465-539.

Brummitt R. K. (ed.), 2000 - Report of the Committee for Spermatophyta: 49. Taxon, 49 (2): 261-278.

Cecere E., Soldano A., Pistarino A. \& Siniscalco C., 2012 Atlante fotografico dei frutti e dei semi della flora del 
Piemonte e della Valle d'Aosta: Oenothera L. (Onagraceae). Bollettino del Museo Regionale di Scienze Naturali, Torino, 29: 75-132, 321-334.

Celesti-Grapow L., Alessandrini A., Arrigoni P. V., Banfi E., Bernardo L., Bovio M., Brundu G., Cagiotti M. R., Camarda I., Carli E., Conti F., Fascetti S., Galasso G., Gubellini L., La Valva V., Lucchese F., Marchiori S., Mazzola P., Peccenini S., Poldini L., Pretto F., Prosser F., Siniscalco C., Villani M. C., Viegi L., Wilhalm T. $\&$ Blasi C., 2009a - Inventory of the non-native flora of Italy. Plant Biosystems, 143 (2): 386-430.

Celesti-Grapow L., Pretto F., Brundu G., Carli E. \& Blasi C. (eds.), 2009b - A thematic contribution to the National Biodiversity Strategy. Plant invasion in Italy, an overview. Ministry for the Environment Land and Sea Protection, Nature Protection Directorate, Roma: 1-32 + Cd-Rom

Celesti-Grapow L., Pretto F., Carli E. \& Blasi C. (eds.), 2010 - Flora vascolare alloctona e invasiva delle regioni d'Italia. Casa Editrice Università La Sapienza, Roma.

Conti F., Abbate G., Alessandrini A. \& Blasi C. (eds.), 2005 - An annotated checklist of the Italian vascular flora. Palombi Editori, Roma.

Cook C. D. K., 1973 - New and noteworthy plants from the northern Italian ricefields. Bericht der Schweizerischen Botanischen Gesellschaft, 83: 54-65.

Cook C. D. K., 1979 - A revision of the genus Rotala (Lythraceae). Boissiera, 29: 1-156.

Debray M., 1963 - Les espèces du genre Bidens introduites en France. Morphologie et géographie. Cahiers des naturalistes; bulletin des naturalistes Parisiens, nouvelle série, 19: 33-50.

Desfayes M., 2005 - Données floristiques pour le Piémont et ses rizières, et pour la Lombardie voisine: plantes aquatiques et palustres. Rivista Piemontese di storia naturale, 26: 73-100.

Dienst, M. 2007 - Cardamine-Neophyt im BodenseeLitoral - wer kennt weitere Fundorte? <http://www. botanik-sw.de/BAS/module/wordpress/?p=52> (retrieved on December 2014).

Dietrich W., Wagner W. L. \& Raven P. H., 1997 - Systematics of Oenothera section Oenothera subsection Oenothera (Onagraceae). Systematic Botany Monographs, 50: 1-234.

Dirkse G., Zonneveld B. \& Duistermaat L., 2015 - Cardamine hamiltonii G.Don - Aziatische veldkers (Brassicaceae) in Nederland. Gorteria, 37: 64-70.

Eckenwalder J. E., 2010 - Populus. In: Flora of North America north of Mexico. Flora of North America Editorial Committee (ed.). Oxford University Press, New York, Oxford, 7: 5-22.

Freckmann R. W. \& Lelong M. G., 2003 - Panicum. In: Flora of North America north of Mexico. Flora of North America Editorial Committee (ed.), Oxford University Press, New York, Oxford, 25: 450-488.

Genovesi P., Scalera R., Brunel S., Roy D. \& Solarz W., 2010 - Towards an early warning and information system for invasive alien species (IAS) threatening biodiversity in Europe. European Environment Agency, Tech. report 5/2010.
Harriman N. A., 1998 - (1357) Proposal to conserve the name Bidens (Asteraceae) with a conserved gender. Taxon, 47 (2): 485-486.

Iamonico D., 2015 - Taxonomic revision of the genus Amaranthus (Amaranthaceae) in Italy. Phytotaxa, 199 (1): 1-84.

Iamonico D., Ardenghi N. M. G., Faggi G., 2015 - Amaranthus palmeri. In: Euro+Med-Checklist Notulae, 4. Raab-Straube E. von \& Raus T. (eds.). Willdenowia, 45 (1): 119-120.

Lihová J., Marhold K., Kudoh H. \& Koch M. A., 2006 Worldwide phylogeny and biogeography of Cardamine flexuosa (Brassicaceae) and its relatives. American Journal of Botany 93 (8): 1206-1231.

Mansanet-Salvador J., Ferrero-Gallego P. P., Ferrando I.\& Laguna E., 2015 - Notas sobre el complejo taxonómico Cardamine flexuosa With. (Cruciferae) y su presencia en la comunidad Valenciana. Flora Montiberica, 59: 72-82.

McNeill J., Barrie F. R., Burdet H. M., Demoulin V., Hawksworth D. L., Marhold K., Nicolson D. H., Prado J., Silva P. C., Skog J. E., Wiersema J. H. \& Turland N. J. (eds.), 2006 - International Code of Botanical Nomenclature (Vienna Code). Adopted by the Seventeenth International Botanical Congress Vienna, Austria, July 2005. Regnum Vegetabile, 146.

McNeill J., Barrie F. R., Buck W. R., Demoulin V., Greuter W., Hawksworth D. L., Herendeen P. S., Knapp S., Marhold K., Prado J., Prud'Homme van Reine W. F., Smith G. F., Wiersema J. H. \& Turland N. J. (eds.), 2012 - International Code of Nomenclature for algae, fungi, and plants (Melbourne Code), Adopted by the Eighteenth International Botanical Congress Melbourne, Australia, July 2011. Regnum Vegetabile, 154.

Mosyakin S. L. \& Robertson K. R., 2003 - Amaranthus. In: Flora of North America north of Mexico. Flora of North America Editorial Committee (ed.). Oxford University Press, New York, Oxford, 4: 410-435.

Peterson P. M., 2003 - Muhlenbergia. In: Flora of North America north of Mexico . Flora of North America Editorial Committee (ed.). Oxford University Press, New York, Oxford, 25: 145-200.

Pistarino A., Forneris G. \& Fossa V., 1999 - Le collezioni di Giacinto Abbà. Catalogo e note critiche delle raccolte botaniche in Piemonte (1965-1998). Cataloghi XII. Museo Regionale di Scienze Naturali, Torino.

Raus T. \& Raabe U., 2006 - Amaranthus palmeri. In: Med-Checklist Notulae, 24. Greuter W. \& Raus T. (eds.). Willdenowia, 36 (2): 719-720.

Recasens J., Conesa J. A., Royo-Esnal A. \& Torra J., 2013 - Amaranthus palmeri en España. ¿Una amenaza inminente? Plantas invasoras resistencias a herbicidas y detección de malas hierbas. XIII Congreso de la Sociedad Española de Malherbología, La Laguna, Spain, 22-24 November 2011: 63-66.

Scholz H., 2002 - Panicum riparium - eine neue indigene Art der Flora Mitteleuropas. Feddes Repertorium, 113 (3-4): 273-280.

Schumacher A., 1941 - Die fremden Bidens-Arten in Mitteleuropa. Feddes Repertorium. Beiheft, 131: 42-93. 
Soldano A., 1977 - Segnalazioni di nuove specie esotiche nel vercellese con considerazioni sulla loro diffusione in Italia e sull'areale di altre entità interessanti già note. Atti dell'Istituto Botanico e del Laboratorio Crittogamico dell'Università di Pavia, serie 6, 11 (1976): 119-129.

Soldano A., 1982 - Naturalizzazione in val Padana di «Amaranthus rudis» Sauer (Amaranthaceae) esotica nuova per la flora italiana. Segnalazione di altre specie di importazione nuove per alcune regioni dell'Italia settentrionale o per qualche provincia del Piemonte. Rivista Piemontese di storia naturale, 3 : 61-70.

Soldano A., 1983 - Per una migliore conoscenza di Oenothera L., subgenere Oenothera, in Italia. II. Descrizione di due nuove specie presenti nella Pianura Padana Occidentale. (Dicotyledonae, Onagraceae). Rivista Piemontese di storia naturale, 4: 127-136.

Soldano A., 1993 - Il genere Oenothera L., subsect. Oenothera, in Italia (Onagraceae). Natura Bresciana, 28: 85-116.

Soldano A. \& Verloove F., 2007 - Nota floristica piemontese n. 83. Panicum gattingeri Nash (Gramineae). In: Note floristiche piemontesi n. 48-91. Selvaggi A., Soldano A. \& Pascale M. (eds.). Rivista Piemontese di storia naturale, 28: 455.

Strother J. L. \& Weedon R. R., 2006 - Bidens. In: Flora of North America north of Mexico. Flora of North America Editorial Committee (ed.). Oxford University Press, New York, Oxford, 21: 205-218.

Thiers B., 2014 onwards - Index herbariorum: a global directory of public herbaria and associated staff. New York Botanical Garden. <http://sweetgum.nybg.org/ $\mathrm{ih} />$ (retrieved on December 2014).

Tison J.-M. \& de Foucault B. (eds.), 2014 - Flora Gallica. Flore de France. Editions Biotope, Mèze.

Varalda G., Forneris G. \& Montacchini F., 1984 - Nuove segnalazioni ed interessanti conferme per la flora del basso Vercellese e dell'Oltrepo' alessandrino. Allionia, 26 (1983-1984): 123-130.

Verloove F., 2008 - Studies within the genus Digitaria Haller (Poaceae, Panicoideae) in southwestern Europe. Candollea, 63 (2): 227-233.

Verloove F., 2014 - A conspectus of Cyperus s.l. (Cyperaceae) in Europe (incl. Azores, Madeira and Canary Islands), with emphasis on non-native naturalized species. Webbia, 69 (2): 179-223.

Verloove F. \& Saiani D., 2015 - Studies in Italian Cyperaceae: 3. Cyperus erythrorhizos, new to Europe, naturalized in Italy. Webbia, doi: 10.1080/00837792.2015.1004871.

Verloove F. \& Sánchez Gullón E., 2008 - New records of interesting xenophytes in the Iberian Peninsula. Acta Botanica Malacitana, 33: 147-167.

Verloove F. \& Selvaggi A., 2011 - Nota floristica piemontese n. 384. Panicum philadelphicum (Poaceae). In: Note floristiche piemontesi n. 309392. Selvaggi A., Soldano A. \& Pascale M. (eds.). Rivista Piemontese di storia naturale, 32: 404405.
Verloove F., Selvaggi A., Soldano A., Banfi E., Galasso G. \& Bouvet D., 2011 - Nota floristica piemontese n. 382. Digitaria violascens (Poaceae). In: Note floristiche piemontesi n. 309-392. Selvaggi A., Soldano A. \& Pascale M. (eds.). Rivista Piemontese di storia naturale, 32: 402-404.

Verloove F. \& Vandenberghe C., 1993 - Nieuwe en interessante graanadventieven voor de Noordvlaamse en Noordfranse flora, hoofdzakelijk in 1992. Dumortiera, 53-54: 35-57. 